\title{
Morphometric analysis and function in vivo and in vitro of corpora lutea from ewes treated with LHRH during seasonal anoestrus
}

\author{
J. D. O’Shea, R. J. Rodgers and P. J. Wright* \\ Departments of Veterinary Preclinical and ${ }^{*}$ Clinical Sciences, University of Melbourne, Parkville, \\ Victoria 3052, Australia
}

\begin{abstract}
Summary. Ovulation was induced by $3 \times 30 \mu \mathrm{g}$ LHRH i.v. at 90-min intervals in anoestrous Corriedale ewes. Plasma LH surges occurred in all of 31 ewes given LHRH, but ovulation occurred in only 16 of these ewes. Luteal weight and plasma progesterone concentration were lower in ewes in which ovulation was induced during anoestrus than in cyclic control ewes in the breeding season, and when data from induced and control ewes were pooled luteal weight was strongly correlated with plasma progesterone concentration $(r=+0.612, P<0.01)$. Five mature corpora lutea (CL) resulting from ovulation induced during anoestrus were compared by morphometric methods with $5 \mathrm{CL}$ from cyclic control ewes. When data from induced and control CL were pooled, luteal volume was positively correlated with total number of cells per CL $\left(r=+0.869, P<0.01\right.$ ) but negatively correlated with number of cells per $\mathrm{mm}^{3}$ luteal tissue ( $r=-0.676, P<0.05$ ), i.e. smaller CL contained fewer cells, but more cells per unit volume. Relative numbers of large to small luteal cells, at $\cong 1: 6$, were similar in LHRH-induced and cyclic control CL. Large and small luteal cells were smaller in induced CL than in control CL, but cytoplasmic : nuclear ratio did not differ between induced and control CL. Basal and LH-stimulated progesterone production by dispersed luteal cells in vitro were lower for CL from LHRH-treated ewes than from controls. However, percentage increase in progesterone production in response to $\mathrm{LH}$ was not different between LHRH-treated and control ewes at any dose rate of LH used.

It is concluded that the small size of CL induced by LHRH is due primarily to the low numbers and small volumes of the luteal cells in these $C L$, and that subnormal luteal weight and subnormal progesterone production per luteal cell contribute to the low plasma progesterone concentrations in ewes treated with LHRH during seasonal anoestrus.
\end{abstract}

\section{Introduction}

Seasonal anoestrus can place an economically significant limitation on the reproductive potential of ewes, and hence many attempts have been made to develop methods for the induction of fertile oestrus in anoestrous ewes. Many studies have demonstrated that the injection of luteinizing hormone-releasing hormone (LHRH) or its analogues can induce ovulation in a variable proportion of ewes during seasonal anoestrus. However, the corpora lutea (CL) resulting from such induced ovulations have commonly been associated with lower-than-normal plasma progesterone concentrations (Crighton, Foster, Haresign \& Scott, 1975; Haresign, Foster, Haynes, Crighton \& Lamming, 1975; McNeilly \& Land, 1979; Swift \& Crighton, 1980), particularly when simple bolus injections of LHRH have been used. 
Little is known of the nature, or causes, of the defects of CL which lead to subnormal plasma progesterone concentrations in these circumstances, although such knowledge could provide a valuable basis for the development of strategies to overcome defective luteal function. In the only study which has so far addressed these questions directly, McNeilly, Hunter, Land \& Fraser (1981) showed that luteal weight was low, and that progesterone production in vitro by slices of luteal tissue was subnormal.

The CL of the sheep contains 2 types of steroidogenic luteal cell, large and small, believed to be of granulosa and theca cell origin respectively (O'Shea, Cran \& Hay, 1979), which occur in normal CL in a ratio of approximately 1:5 (Rodgers, O'Shea \& Bruce, 1984). Both cell types produce progesterone in vitro, with large luteal cells showing a higher basal progesterone production on a per cell basis (Fitz, Mayan, Sawyer \& Niswender, 1982; Rodgers \& O'Shea, 1982). However, the progesterone secretory response to $\mathrm{LH}$ appears to reside largely or entirely in the small luteal cells (Fitz et al., 1982; Rodgers, O'Shea \& Findlay, 1983). Hence in understanding the subnormal progesterone-producing ability of many $C L$ resulting from induced ovulation during anoestrus, it would be useful to know how the cellular composition of such CL compares with that of normal cyclic CL. In particular, data on the absolute and relative numbers of large and small luteal cells, and on the volumes of the individual cells of each type, could help to explain the cellular basis for the relationship between luteal weight and progesterone production.

This paper reports an electron microscopic morphometric study comparing the cellular and other components of CL induced by LHRH during anoestrus with those of normal cyclic CL in Corriedale ewes, together with data on plasma LH and progesterone levels, luteal weight, and progesterone production by dispersed luteal cells in vitro.

\section{Materials and Methods}

\section{Animals and treatments}

The ewes in this study were from a flock of mature Corriedale ewes maintained under natural lighting conditions on above-maintenance rations at the Veterinary Clinical Centre, Werribee. The ewes had lambed in June 1982 and the newly born lambs had been separated from their dams within a day of parturition. A vasectomized ram was continually present with the ewes throughout the lambing period and until completion of the experiments. No ewes mated during AugustNovember, and all experiments involving induction of ovulation during anoestrus were performed in October and November. Plasma progesterone concentration was $<1 \mathrm{ng} / \mathrm{ml}$ in all ewes at the start of the experiments and no CL were visible in any ovaries of saline-treated ewes examined at laparotomy.

Ovulation was induced in anoestrous ewes by three intravenous (i.v.) injections of $30 \mu \mathrm{g} \mathrm{LHRH}$ (Peninsula Laboratories, San Carlos, U.S.A.) in $2 \mathrm{ml}$ saline vehicle $(0 \cdot 154 \mathrm{M}-\mathrm{NaCl}, 0 \cdot 1 \% \mathrm{w} / \mathrm{v}$ gelatin) at 90 -min intervals (Day 0). Anoestrous control ewes were given saline vehicle only. Two days later (Day 2) laparotomy was performed under pentobarbitone sodium anaesthesia on a randomly-selected sample of LHRH-treated and vehicle-treated control ewes to detect recent ovulation and the presence of any pre-existing CL. Ovaries containing CL for morphometry $(n=5)$ were collected under pentobarbitone anaesthesia on Day 9 , and CL for functional studies $(n=6)$ were collected on Days 8,9 or 10 . Blood samples were collected by jugular venepuncture at $0,1 \cdot 5$, $3.0,4 \cdot 5$ and $6.0 \mathrm{~h}$ after the first injection of LHRH or saline vehicle, and then daily until the day of collection of CL. Plasma was stored at $-20^{\circ} \mathrm{C}$ until assayed for $\mathrm{LH}$ or progesterone.

Cyclic control $\mathrm{CL}$ were collected from ewes from the same flock during the breeding season (April and May). These ewes were checked daily for expression of oestrus by marking with a vasectomized ram, and CL for morphometry $(n=5)$ and functional $(n=6)$ studies were collected on Day 9 of the oestrous cycle (Day $0=$ oestrus). CL were collected only from ewes which had 
shown at least 3 previous periods of oestrous activity during the breeding season. Jugular venous blood samples were collected before anaesthesia on Day 9 , and stored at $-20^{\circ} \mathrm{C}$.

\section{Collection and processing of $C L$}

Morphometry. Ovaries containing $\mathrm{CL}$, together with their extrinsic blood vessels, were collected either by laparotomy under pentobarbitone anaesthesia or immediately after euthanasia by exsanguination under pentobarbitone anaesthesia. The ovarian artery was rapidly cannulated close to the hilus of the ovary, and blood flushed from the ovarian vessels by perfusion with $5 \mathrm{ml}$ Ringer's balanced salt solution from a hypodermic syringe under gentle manual pressure at room temperature. Then, $10 \mathrm{ml} \mathrm{3 \%}$ glutaraldehyde in $0.1 \mathrm{M}$-cacodylate buffer, $\mathrm{pH} 7 \cdot 3$, at $4^{\circ} \mathrm{C}$, was perfused through the ovary in the same manner at $\cong 1 \mathrm{ml} / \mathrm{min}$. After perfusion, ovaries were stored for up to $2 \mathrm{~h}$ in the same fixative at $4^{\circ} \mathrm{C}$. CL were then dissected from the ovaries and weighed. A complete cross-sectional slice of tissue $\simeq 1 \mathrm{~mm}$ thick was cut from the centre of each $\mathrm{CL}$, in a plane parallel to the surface of the ovary. Each slice was then divided into 4 equal quadrants, and from each quadrant 2 blocks of tissue $\simeq 1 \mathrm{~mm}^{3}$ were taken for electron microscopy, one from the outer part of the quadrant and the other from the inner part. Outer blocks were taken from tissue about one third of the way from the capsule of the CL to its centre, and inner blocks from tissue about two thirds of this distance. To represent the outer and inner regions of the luteal tissue in their proper proportions, all 4 blocks from the outer part, but only 1 randomly-selected inner block, were used for morphometry. These blocks were then placed in $3 \%$ glutaraldehyde for $1 \mathrm{~h}$ at $4 \%$, rinsed in cacodylate buffer, and post-fixed in $1 \%$ osmium tetroxide in distilled water for $2 \mathrm{~h}$ at room temperature. Blocks were stained for $30 \mathrm{~min}$ in $0.5 \%$ aqueous uranyl acetate, dehydrated in alcohol and embedded in araldite (Durcupan: Fluka, Buchs, Switzerland). Thin sections were stained with uranyl acetate and lead citrate, and examined in a Philips EM 300 electron microscope. For each block, 5 randomly-selected complete grid squares of a 200-mesh grid were photographed at a magnification of $\times 1000$. Prints for morphometric examination were produced at a final magnification of $\times 2020$ or $\times 2280$.

The specific gravity of the tissue of each $\mathrm{CL}$ was determined using a flotation method in solutions of copper sulphate of known specific gravity (Long, King \& Sperry, 1968). Volume was then calculated by dividing luteal weight by specific gravity. The volume of any central cavity in CL was calculated from 2 measured diameters of the cavity at $90^{\circ}$ to one another, and subtracted from the volume as calculated above.

Cell separation and function in vitro. CL, 2 from ewes on each of Days 8, 9 and 10 after LHRH administration and 6 from ewes on Day 9 of the oestrous cycle, were processed as described in detail previously (Rodgers \& O'Shea, 1982). Briefly, ovaries were initially placed in ice-cold KrebsRinger-bicarbonate solution. CL were then dissected from the ovary, weighed, and small samples of tissue taken for determination of progesterone content and histology. The remaining tissue was sliced and then dispersed by collagenase and trypsin/EGTA treatments. An aliquant of cells was mixed with trypan blue (Phillips, 1973) and viable cells counted in a haemocytometer. Cells were classified, on size, as endothelial cells, small luteal cells or large luteal cells. This method of cell classification has been previously validated using electron microscopy (Rodgers \& O'Shea, 1982).

Aliquants $(1.0 \mathrm{ml})$ of cells were incubated in Dulbecco's modified Eagle's medium containing $10 \%$ fetal calf serum for $12 \mathrm{~h}$ at $37^{\circ} \mathrm{C}$ in a humidified atmosphere of $5 \% \mathrm{CO}_{2}$ in air. The cells were then sonicated in their incubation medium before progesterone concentrations were determined. Net progesterone production was calculated as that present in the incubation well at the end of incubation less that at the start.

In-vitro treatments included ovine LH (NIAMDD No. 21, biopotency 2.5 times NIH-LH-S1 ; $0,0 \cdot 15,6 \cdot 0$ and $100 \cdot 0 \mathrm{ng} / \mathrm{ml}$ ), oxytocin (Calbiochem-Behring Australia Pty Ltd, Carlingford, Australia; 23.2 i.u. $/ \mathrm{mg} ; 500 \mathrm{mi} . \mathrm{u} . / \mathrm{ml}$ incubation medium), and prostaglandins (PG) F- $2 \alpha, \mathrm{E}-1$ and E-2 (The Upjohn Co., Kalamazoo, Michigan, U.S.A.; $50 \mathrm{ng} / \mathrm{ml}$ incubation medium, PGF-2 $\alpha$ dose calculated in acid equivalents). 


\section{Morphometric methods}

Methods used for measurement of volume density, cell number and cell volume have been reported in detail elsewhere (Rodgers et al., 1984), and will be summarized briefly here.

Volume density was determined by the point-counting method (Weibel, 1979), using a 21-bar, 42-point (M42) grid, of $\cong 131 \cdot 3 \mathrm{~cm}^{2}$, reproduced as a transparent sheet and dropped once onto each micrograph. Thus 42 points were counted for each micrograph, 5 micrographs from each block, 5 blocks from each animal and 5 animals per group, a total of 5250 points per group. Volume density of each component of the tissue, as a percentage, was calculated from the number of 'hits' on that component, divided by the total number of hits and multiplied by 100 .

Cell numbers per unit volume of fixed tissue $\left(\mathrm{N}_{\mathrm{v}}\right)$ were calculated using the formula

$$
\mathrm{N}_{\mathrm{v}}=\frac{1}{\beta} \times \frac{\mathrm{N}_{\mathrm{A}}^{1 \cdot 5}}{\mathrm{~V}_{\mathrm{v}}^{0 \cdot 5}} \quad \text { (Formula 2.83: Weibel, 1979) }
$$

where $\beta$ is a correction factor based on nuclear shape, $N_{A}$ is the number of nuclei of each type per unit area of micrograph, and $V_{v}$ is the volume fraction of nuclei (the combined area of all nuclei of a particular type divided by the area of the electron nicrographs). Nuclei of large and small luteal cells, and other cell types, were given a value of 1.382 for $\beta$. Endothelial cells and pericytes were given a value of 1.9 , and fibrocytes a value of 1.7 (Rodgers et al., 1984). The areas of electron micrographs, and of individual nuclei, were measured using an image analyser (Videoplan: Carl Zeiss, Obercochen, West Germany). Correction of these values for shrinkage was based on the use of a linear shrinkage factor of $87.7 \%$ (Rodgers et al., 1984), which takes account of tissue shrinkage during embedding and sectioning, and also of any errors in magnification in photographic printing or in the electron microscope. Total cell numbers per $\mathrm{CL}$ were the product of cell numbers per unit volume and the volume of the CL. The mean volume of each cell type was calculated by dividing volume density $(\%)$ by the number of cells per unit volume of tissue. Cytoplasmic: nuclear ratios were calculated from volume density data, in which 'hits' on nuclei and cytoplasm were recorded separately for each cell type.

\section{Hormone assays}

Plasma LH levels were measured in a double-antibody radioimmunoassay (Wright, Geytenbeek, Clarke \& Findlay, 1980) using NIH-LH-S18 (biopotency 1.03 $\times$ NIH-LH-SI) as standard. Hormone concentrations and assay quality control data were calculated by the methods and computer programme of Burger, Lee \& Rennie (1972). Four assays were used in this study. Assay sensitivity was $0.6 \mathrm{ng} / \mathrm{ml}$ and the inter-assay coefficients of variation were $14 \%$ and $16 \%$ for plasma pools of 3.8 and $44.2 \mathrm{ng} \mathrm{LH} / \mathrm{ml}$ respectively. The intra-assay coefficient of variation was $<20.0 \%$ between 1.8 and $91.0 \mathrm{ng} / \mathrm{ml}$. Samples with concentrations of $\mathrm{LH}$ above this range were diluted 1 in 10 with assay buffer and reassayed.

Progesterone concentrations in plasma, luteal tissues and incubation medium containing sonicated cells were determined by the radioimmunoassay described by Hossain, Lee, Clarke \& O'Shea (1979). The assay has been validated for assay of extracts of luteal tissue and ovine plasma (Rodgers \& O'Shea, 1982) and unextracted diluted incubation medium containing sonicated cells (Rodgers et al., 1983). The mean intra-assay coefficient of variation was $8.7 \%$ at $1.5 \mathrm{ng} / \mathrm{ml}$ and the assay sensitivity was $0.08 \mathrm{ng} / \mathrm{ml}$ or $8 \mathrm{pg} /$ tube (10 assays). When comparisons were to be made between control and induced CL, samples were assayed in the same assay, except for the samples from the in-vitro experiments, for which 4 assays were used. The inter-assay coefficient of variation of these assays was $13.9 \%$ at $2 \cdot 1 \mathrm{ng} / \mathrm{ml}$.

\section{Statistical analysis}

Data were analysed by Student's $t$ test, using arcsine transformed data in the case of percentages, or by product-moment-correlation coefficient (Sokal \& Rohlf, 1969). 


\section{Results}

All of 31 ewes treated with LHRH during the anoestrous season showed preovulatory type surge releases of $\mathbf{L H}$ (Text-fig. 1) defined on the basis of at least two consecutive plasma samples $>20$ $\mathrm{ng} / \mathrm{ml} \mathrm{LH}$ : only 1 of 9 ewes in the vehicle-treated group showed a surge release of LH. Approximately half of the LHRH-treated ewes (16/31) ovulated in response to LHRH treatment, as judged by the presence of a mature CL 8-10 days later, and by plasma progesterone profiles (Text-fig. 1). Of these $16 \mathrm{CL}, 10$ were in ewes in which an additional laparotomy was performed $48 \mathrm{~h}$ after $\mathrm{LHRH}$ administration, and evidence of follicular rupture in the form of a recent ovulation point corresponded in position with the subsequently observed CL in all cases. None of the vehicle-treated ewes ovulated. There were no significant differences in plasma $\mathrm{LH}$ concentrations between LHRH-treated ewes that ovulated and those that did not (Text-fig. 1). Plasma progesterone concentrations rose steadily in the days after LHRH treatment in ewes that ovulated. In the ewes that did not ovulate, and in the vehicle-treated ewes, plasma progesterone concentrations remained low (Text-fig. 1). When data from ewes in which ovulation was induced by LHRH were combined with those from cyclic control ewes, plasma progesterone concentrations on the day of collection of CL were positively correlated with luteal weight (Text-fig. 2).

(a)

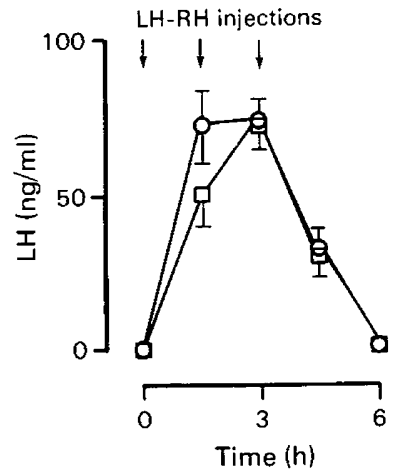

(b)

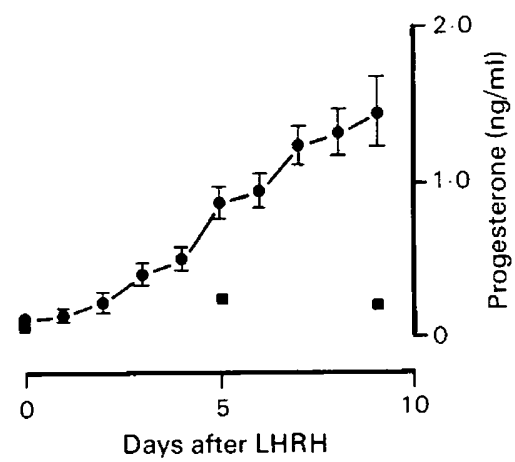

Text-fig. 1. Plasma concentrations (mean \pm s.e.m.) of (a) $\mathrm{LH}$ and (b) progesterone in anoestrous ewes that ovulated $(0 ; n=16 ; 0, n=14)$ or did not ovulate $(\square, n=15 ; \square, n=$ 16) in response to LHRH administration.

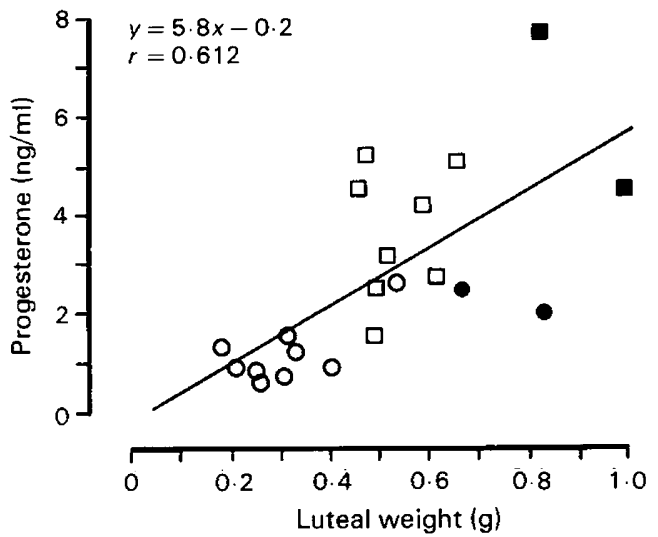

Text-fig. 2. Plasma progesterone concentrations on the day $\mathbf{C L}$ were collected against luteal weight in anoestrous ewes in which ovulation was induced by LHRH $(O, O)$ and in cyclic control ewes $(\square, \square)$. Single ovulating ewes $(O, \square)$ and twin ovulating ewes $(\boldsymbol{O}, \square)$ are represented by different symbols. The line of best fit is shown. 
The early laparotomy performed on some ewes 2 days after $\mathrm{LHRH}$ to ensure that CL subsequently collected were the result of fresh ovulations following LHRH treatment, had no apparent effect on subsequent $C L$ formation. The mean \pm s.e.m. weights of the CL from ewes in which laparotomy was performed $(346 \cdot 1 \pm 37 \cdot 2 \mathrm{mg})$ were not significantly different from those of the CL of ewes that did not undergo early laparotomy $(301.7 \pm 21.3 \mathrm{mg})$.

\section{Morphometry}

Five CL from ewes in which ovulation was induced during anoestrus, and 5 from cyclic control ewes (each group including $4 \mathrm{CL}$ from single-ovulating ewes and $1 \mathrm{CL}$ from a twin-ovulating ewe) were examined. The volume of the CL was lower in the anoestrous group ( $310 \pm 45$ compared with $520 \pm 34 \mathrm{~mm}^{3} ; P<0.01$ ). Plasma progesterone concentration on Day 9 was also lower in the ewes in which ovulation was induced by LHRH $(1.39 \pm 0.39$ compared with $4.34 \pm 0.32 \mathrm{ng} / \mathrm{ml} ; P<$ $0 \cdot 01$ ). Representative examples of the morphology of the luteal tissue from the 2 groups are shown in Pl. 1, Figs 1 \& 2.

Differences in the proportions of luteal volume occupied by its constituent elements between control and induced CL were generally not very great (Table 1). The greatest difference was in the volume occupied by vascular lumina, a component which is particularly likely to be influenced by perfusion pressures, with the mean value for induced CL higher than that for the controls. Since these are percentage values, a rise in one component is necessarily associated with a lowering in some or all other components, and this could account in part for the observed differences in small luteal cell values.

On a per unit volume basis (Table 2) the total number of cells in LHRH-induced CL was almost $30 \%$ higher than in the cyclic controls, although amongst the individual cell types a significant difference was observed only for endothelial cells and pericytes. However, in spite of the greater numbers of cells per unit volume in LHRH-induced CL, the percentage representation of the various cell types showed little if any differences and the ratio of large luteal cells to small luteal cell was unchanged at $\cong 1: 6$. When values for all $10 \mathrm{CL}$ were pooled, a significant negative correlation was demonstrable between luteal volume and number of cells per unit volume for both endothelial cells/pericytes and for large luteal cells, as well as for total cells.

Conversion of these data to absolute numbers of cells per CL (Table 3) provided estimates of mean total cell numbers which were higher, although not significantly so, in cyclic control CL in every case. In terms of total cell numbers per CL the LHRH-induced CL contained only approximately $75 \%$ of the number of cells in control CL. Although $t$ tests did not show significant

Table 1. Volume density $(\%)$ of the cellular and non-cellular components of cyclic control $\mathrm{CL}$ and $\mathrm{CL}$ induced by LHRH administration during seasonal anoestrus in sheep

\begin{tabular}{lrc}
\hline & \multicolumn{2}{c}{ Type of CL } \\
\cline { 2 - 3 } Component of luteal tissue & Cyclic control & LHRH-induced \\
\hline Endothelial cells and pericytes & $12 \cdot 8 \pm 1 \cdot 1$ & $14 \cdot 1 \pm 1 \cdot 0$ \\
Large luteal cells & $28 \cdot 3 \pm 2 \cdot 1$ & $22 \cdot 9 \pm 2 \cdot 4$ \\
Small luteal cells & $22 \cdot 2 \pm 1 \cdot 4$ & $15 \cdot 9 \pm 1 \cdot 5^{*}$ \\
Fibrocytes & $5 \cdot 6 \pm 1 \cdot 3$ & $7 \cdot 9 \pm 1 \cdot 8$ \\
Other cell types & $3 \cdot 2 \pm 0 \cdot 5$ & $2 \cdot 5 \pm 0.4$ \\
Vessel lumen & $12 \cdot 2 \pm 1 \cdot 1$ & $23 \cdot 3 \pm 2 \cdot 4^{* *}$ \\
Intercellular space & $15 \cdot 7 \pm 3 \cdot 1$ & $13 \cdot 4 \pm 2 \cdot 1$ \\
\hline
\end{tabular}

Values are mean \pm s.e.m. for $5 \mathrm{CL} /$ group.

${ }^{*} P<0.05,{ }^{* *} P<0.01$ ( $t$ tests) compared with control value. 

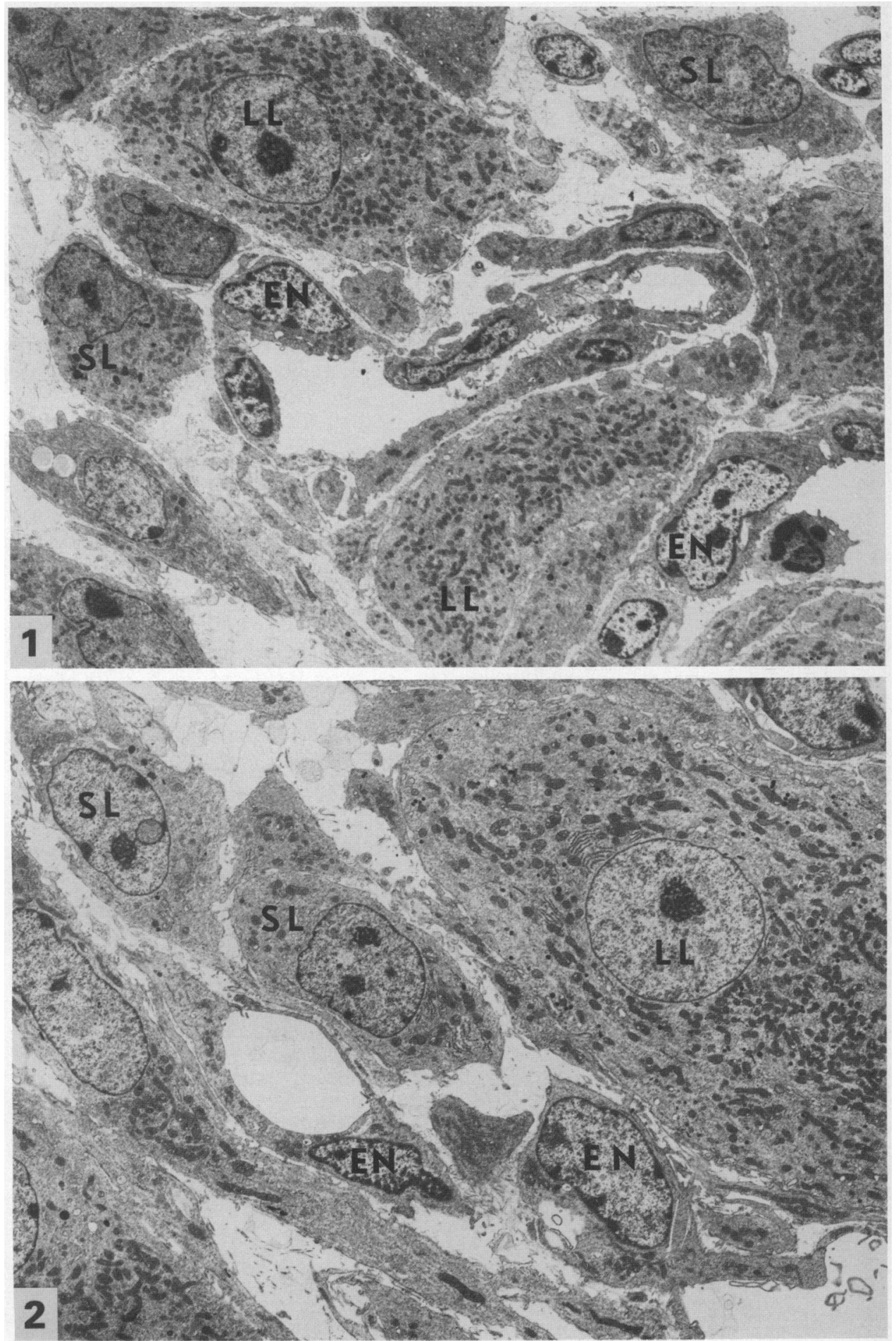

Figs 1 and 2. Representative examples of the luteal tissues used for morphometry. Tissue from a CL induced by LHRH in anoestrus (Fig. 1) is similar in composition and organization to that from a cyclic control $\mathrm{CL}$ (Fig. 2). $\mathrm{LL}=$ large luteal cell, $\mathrm{SL}=$ small luteal cell, $\mathrm{EN}=$ endothelial cell. $\times 2500$. 
Table 2. Number of cells per unit volume in luteal tissue from cyclic control CL and CL induced by LHRH administration during seasonal anoestrus in sheep, and correlation between number of cells per unit volume and volume of $\mathrm{CL}$

\begin{tabular}{|c|c|c|c|c|}
\hline \multirow[b]{2}{*}{ Cell type } & \multicolumn{2}{|c|}{$\begin{array}{l}\text { No. of cells per } \mathrm{mm}^{3} \times 10^{3}(\%) \\
(5 \mathrm{CL} \text { per group })\end{array}$} & \multicolumn{2}{|c|}{$\begin{array}{c}\text { Correlation coefficient } \\
(10 \mathrm{CL})\end{array}$} \\
\hline & Cyclic control & LHRH-induced & $r$ & $P$ \\
\hline $\begin{array}{l}\text { Endothelial cells and pericytes } \\
\text { Large luteal cells } \\
\text { Small luteal cells } \\
\text { Fibrocytes } \\
\text { Other cell types }\end{array}$ & $\begin{array}{c}173 \cdot 8 \pm 12 \cdot 1(45 \cdot 2) \\
18 \cdot 4 \pm 1 \cdot 3(4 \cdot 8) \\
109 \cdot 9 \pm 13 \cdot 4(28 \cdot 6) \\
32 \cdot 7 \pm 4 \cdot 5(8 \cdot 5) \\
50 \cdot 0 \pm 4 \cdot 9(12 \cdot 9)\end{array}$ & $\begin{array}{c}225 \cdot 8 \pm 11 \cdot 6^{*}(45 \cdot 6) \\
23 \cdot 0 \pm 1 \cdot 3(4 \cdot 6) \\
132 \cdot 3 \pm 13 \cdot 4(26 \cdot 7) \\
62 \cdot 4 \pm 12 \cdot 5(12 \cdot 6) \\
51 \cdot 9 \pm 5 \cdot 8(10 \cdot 5)\end{array}$ & $\begin{array}{l}-0.746 \\
-0.667 \\
-0.299 \\
-0.506 \\
+0.338\end{array}$ & $\begin{array}{l}<0.05 \\
<0.05 \\
\text { N.S. } \\
\text { N.S. } \\
\text { N.S. }\end{array}$ \\
\hline Total & $384.8 \pm 26 \cdot 4(100)$ & $495 \cdot 4 \pm 8 \cdot 1^{* *}(100)$ & -0.676 & $<0.05$ \\
\hline
\end{tabular}

Values are mean \pm s.e.m.

${ }^{*} P<0.05,{ }^{* *} P<0.01$ ( $t$ tests) compared with control value; N.S. $=$ not significant.

Table 3. Number of cells per CL in cyclic control CL and CL induced by LHRH administration during seasonal anoestrus in sheep, and correlation between number of cells per $C L$ and volume of $C L$

\begin{tabular}{lccccc}
\hline & \multicolumn{2}{c}{$\begin{array}{c}\text { No. of cells per CL } \times 10^{6} \\
\text { (5 CL per group) }\end{array}$} & & \multicolumn{2}{c}{$\begin{array}{c}\text { Correlation } \\
\text { coefficient } \\
\text { (10 CL) }\end{array}$} \\
\cline { 2 - 3 } \multicolumn{1}{c}{ Cell type } & Cyclic control & LHRH-induced & & $r$ & $P$ \\
\hline Endothelial cells and pericytes & $89.9 \pm 7.2$ & $69.1 \pm 8.9$ & & +0.825 & $<0.01$ \\
Large luteal cells & $9.6 \pm 0.9$ & $7.0 \pm 0.9$ & & +0.845 & $<0.01$ \\
Small luteal cells & $57.5 \pm 8.1$ & $40.8 \pm 7.2$ & & +0.751 & $<0.05$ \\
Fibrocytes & $17.4 \pm 3.1$ & $15.4 \pm 4.9$ & & +0.241 & N.S. \\
Other cell types & $26.5 \pm 4.0$ & $16.8 \pm 4.0$ & & +0.870 & $<0.01$ \\
\hline Total & $200.8 \pm 20.6$ & $152.6 \pm 20.6$ & & +0.869 & $<0.01$ \\
\hline
\end{tabular}

Values are mean \pm s.e.m.

N.S. $=$ not significant.

differences between individual groups, there was a positive correlation between luteal volume and cell numbers per CL for all cell types except fibrocytes.

As shown in Table 4, while the proportions of cytoplasm to nucleus in all of the major cell types in cyclic control and LHRH-induced CL were closely similar, absolute volumes of the individual cells tended to be lower in the induced CL. These differences were significant, and substantial, in both large and small luteal cells.

\section{Cell separation and function in vitro}

The mean ( \pm s.e.m.) weight of the 6 induced CL used in this study was lower than that of the 6 control ewes ( $304 \pm 31$ compared with $504 \pm 26 \mathrm{mg}, P<0.01$ ). Plasma progesterone concentration on the day of collection of CL was also lower in the ewes in which ovulation was induced $(1.4 \pm 0.6$ compared with $4.1 \pm 1.3 \mathrm{ng} / \mathrm{ml}, P<0.05)$. However, luteal tissue progesterone content was not significantly lower $(28.8 \pm 4.0$ and $41.8 \pm 5.1 \mathrm{ng} / \mathrm{mg}, P>0.05)$ in induced and control CL.

The mean percentages of endothelial cells, small luteal cells and large luteal cells isolated from 
Table 4. Volume and cytoplasmic : nuclear ratio of four major cell types in cyclic control CL and CL induced by LHRH administration during seasonal anoestrus in sheep

\begin{tabular}{|c|c|c|c|c|}
\hline \multirow[b]{2}{*}{ Cell type } & \multicolumn{2}{|c|}{ Cell volume $\left(\mu \mathrm{m}^{3} \times 10^{3}\right)$} & \multicolumn{2}{|c|}{ Cytoplasmic : nuclear ratio } \\
\hline & Cyclic control & LHRH-induced & Cyclic control & LHRH-induced \\
\hline Endothelial cells and pericytes & $0.75 \pm 0.08$ & $0.62 \pm 0.04$ & $3 \cdot 46 \pm 0.37$ & $3.41 \pm 0.42$ \\
\hline Large luteal cells & $15.60 \pm 1.34$ & $9.91 \pm 0.68^{* *}$ & $23.40 \pm 1.33$ & $21 \cdot 25 \pm 0.44$ \\
\hline Small luteal cells & $2 \cdot 12 \pm 0.26$ & $1.22 \pm 0.08^{*}$ & $7.43 \pm 0.68$ & $7.90 \pm 1.57$ \\
\hline Fibrocytes & $1.69 \pm 0.32$ & $1 \cdot 25 \pm 0 \cdot 11$ & $5 \cdot 43 \pm 0.27$ & $6.04 \pm 0.50$ \\
\hline
\end{tabular}

Values are mean \pm s.e.m. for $5 \mathrm{CL} /$ group.

${ }^{*} P<0.05,{ }^{* *} P<0.01$ ( $t$ tests) compared with control value.

Table 5. Net progesterone production in vitro $\left(\mathrm{ng} / 10^{4}\right.$ luteal cells $/ 12 \mathrm{~h}$ ) by dispersed cells from cyclic control $\mathrm{CL}$ and $\mathrm{CL}$ induced by LHRH administration during seasonal anoestrus in sheep

\begin{tabular}{|c|c|c|}
\hline \multirow[b]{2}{*}{ Treatment } & \multicolumn{2}{|c|}{ Type of CL } \\
\hline & Cyclic control & LHRH-induced \\
\hline Basal & $133 \cdot 1 \pm 12 \cdot 0$ & $68 \cdot 0 \pm 12 \cdot 5$ \\
\hline Oxytocin (500 mi.u./ml) & $144 \cdot 3 \pm 15 \cdot 4$ & $64.9 \pm 8.4$ \\
\hline PGF- $2 \alpha(50 \mathrm{ng} / \mathrm{ml})$ & $130.8 \pm 15.0$ & $48 \cdot 2 \pm 5 \cdot 7$ \\
\hline PGE-2 (50 ng/ml) & $173.7 \pm 19 \cdot 3^{*}$ & $76.0 \pm 10.9$ \\
\hline PGE-1 (50 ng/ml) & $183.6 \pm 13 \cdot 6^{* *}$ & $72 \cdot 5 \pm 10 \cdot 7$ \\
\hline LH $(0.15 \mathrm{ng} / \mathrm{ml})$ & $243 \cdot 3 \pm 38 \cdot 4^{*}$ & $106 \cdot 3 \pm 12 \cdot 9 * *$ \\
\hline LH $(6.0 \mathrm{ng} / \mathrm{ml})$ & $316.9 \pm 36.5^{* *}$ & $124 \cdot 9 \pm 15 \cdot 6^{* *}$ \\
\hline $\mathrm{LH}(100 \mathrm{ng} / \mathrm{ml})$ & $335 \cdot 2 \pm 37 \cdot 8^{* *}$ & $128 \cdot 2 \pm 15 \cdot 9^{* *}$ \\
\hline
\end{tabular}

Values are mean \pm s.e.m. for $6 \mathrm{CL} /$ group.

Significant differences from net basal progesterone production within each type of $\mathrm{CL}$ shown as ${ }^{*} P<0.05,{ }^{* *} P<0.01$ (paired $t$ tests).

the LHRH-induced CL and cyclic control CL were 85.8 and $81 \cdot 8,11.6$ and 15.4 and 2.6 and $2 \cdot 8 \%$ respectively, and not significantly different.

The results of the in-vitro experiments are shown in Table 5. Progesterone production, expressed per luteal cell, was significantly $(P<0.01)$ greater by luteal cells from cyclic control CL than those from LHRH-induced CL in anoestrous ewes. Significant differences were present both in basal progesterone production and following all of the treatments used. However, induced CL were equally responsive to a high dose of $\mathrm{LH}(100 \mathrm{ng} / \mathrm{ml})$ in terms of maximal mean increase of basal progesterone production, and were as sensitive to $\mathrm{LH}$ as were cyclic control CL $(64 \%$ of maximal response to $\mathrm{LH}$ occurring at $0.15 \mathrm{ng} \mathrm{LH} / \mathrm{ml}$ compared with $55 \%$ for cyclic control $\mathrm{CL}$ ). Oxytocin and PGF- $2 \alpha$ had no effects on progesterone production by either type of CL. However, cyclic control CL, but not LHRH-induced CL, responded to PGE-1 and PGE-2 with significant increases in progesterone production.

\section{Discussion}

Ewes in the present study, as in that of McNeilly et al. (1981), responded to LHRH administered during seasonal anoestrus in one of two ways. About half of the treated animals ovulated and produced CL of subnormal size, though larger than those observed by McNeilly et al. (1981), while 
the remaining half failed to ovulate. Reasons for this divergence in response to LHRH are not obvious, as no significant differences were detected in the LH surges between ewes that did or did not ovulate. Differences at the ovarian level, in terms of follicular maturity and responsiveness to a surge release of $\mathrm{LH}$, are the most likely explanation of these findings.

Briefly summarized, the morphometric data from this study show that reduced luteal volume was associated with reduced numbers of luteal and other cells per CL, and also with reduced size of the individual luteal cells, relative both to cyclic control CL in the present study and to normal cyclic CL as reported elsewhere (Rodgers et al., 1984).

Apart from these two quantitative differences from the controls, CL produced after LHRH injection during anoestrus were essentially normal in structure. The numerical ratio of large to small luteal cells, and the ratios of cytoplasm to nucleus in each of these cell types, were closely similar to those in control CL. Also, apart from an apparent difference in relation to vascular lumina, the volume density of the various components of the luteal tissue showed little difference in the two populations of CL.

As has been observed in many previous studies, plasma progesterone concentrations in those animals that did ovulate in the present experiments were substantially lower than those in the breeding season. This would be a reflection of a lower-than-normal production of progesterone, an increase in clearance rate, or both. Clearance rates for progesterone have not been studied during seasonal anoestrus in ewes, although Bedford, Harrison \& Heap (1972) found an elevation in progesterone clearance rate during lactational anoestrus. However, in view of the low plasma levels of progesterone in these animals, Bedford et al. (1972) suggested that raised numbers of unsaturated binding sites in the tissues may have contributed to the elevation in clearance rate. It was also suggested that increased cardiac output and hepatic blood flow associated with lactation could have been responsible for the observed increase in clearance rate (Bedford et al., 1972), changes which could not apply during seasonal anoestrus as in the present experiments.

Several lines of evidence suggest that the low plasma concentrations of progesterone in the present study were due, at least in part, to lower-than-normal production of progesterone. Thus the weights of the CL were low, and progesterone production per luteal cell in vitro was also low. As shown here, luteal volume is positively and closely correlated with the numbers of luteal cells per $\mathrm{CL}$, and hence in small CL there are fewer than normal luteal cells, each with a subnormal progesterone-producing capacity, at least in vitro. These findings also accord with the observation of McNeilly et al. (1981) that slices of luteal tissue from LHRH-induced CL produced less progesterone per unit weight than did those from normal cyclical CL.

While basal levels of progesterone production in vitro by luteal cells from LHRH-treated anoestrous ewes were low, responsiveness to $\mathrm{LH}$ was not suppressed. Similar findings were recorded by McNeilly et al. (1981). In terms of the contributions of the two types of luteal cells to progesterone production in sheep, on a per cell basis the large luteal cells show a higher basal progesterone production than the small luteal cells, while responsiveness to LH is primarily a property of small luteal cells (Fitz et al., 1982; Rodgers \& O'Shea, 1982; Rodgers et al., 1983). No evidence was seen in this study of a reduced proportion of large to small luteal cells among dissociated cell populations, which might have accounted for lowered basal progesterone production, nor was any change in the proportions of the two luteal cell types seen by morphometric examination. It is possible, however, that reduced volume of the individual luteal cells may have contributed to lowering of basal progesterone production in vitro.

The reasons why CL forming after bolus administration of LHRH during anoestrus are often structurally and functionally 'defective' to various degrees, even though preovulatory LH surges reaching equivalent concentrations of $\mathrm{LH}$ to those of normal cycles are commonly achieved, are not known. However, two possibilities, which are not mutually exclusive, are suggested by the present morphometric data. The first, which is consistent with data showing that PMSG pretreatment increased the progesterone-producing capacity of $\mathrm{CL}$ formed after ovulation induced by LHRH (Haresign \& Lamming, 1978), and with data showing normal luteal function after prolonged 
administration of LH or LHRH (McNatty, Gibb, Dobson \& Thurley, 1981), is that defects in CL arising under these conditions are a result of defects in the follicles from which they originate. Failure of ovulation in many treated ewes as observed in this and other studies would also accord with the possibility that defective CL result from the ovulation of defective follicles.

Defects in follicles ovulating in response to LHRH might have a biochemical basis, but the simplest explanation of the present data on cell numbers would be that such follicles have variable, and often suboptimal, numbers of granulosa and/or theca cells. A primary deficiency of granulosa cells seems likely to be the more significant, since these cells appear to have little, if any, capacity for mitosis in the post-ovulatory period (McClellan, Diekman, Abel \& Niswender, 1975; O'Shea et al., 1980), while theca-derived luteal cells continue to divide for at least 5 days after ovulation (O'Shea et al., 1980). The occurrence of a normal ratio of numbers of large and small luteal cells in $\mathrm{CL}$ induced during anoestrus, regardless of absolute numbers of these two cell types, would therefore fit a hypothesis that granulosa cell numbers at ovulation determine large luteal cell numbers in the $\mathrm{CL}$, and that these in turn in some way control the number of small luteal cells formed during luteinization. Quantitative studies of granulosa cell numbers in follicles induced to ovulate during anoestrus, and comparison with numbers in normal preovulatory follicles and with numbers of large luteal cells, are needed to evaluate these predictions.

A second possible explanation of sub-normal luteal cell numbers and sizes in LHRH-treated anoestrous ewes is that these deficiencies result from suboptimal luteotrophic support in the postovulatory period. While the hormonal control of the degree of hypertrophy and/or hyperplasia of granulosa and theca cells following ovulation in the ewe has not been defined, it is well established that LH is luteotrophic in relation to progesterone secretion. It has also been demonstrated that luteal tissue from CL induced during anoestrus possesses normal levels of binding of hCG and responds normally to LH stimulation in vitro (McNeilly et al., 1981). An examination of circulating LH levels in the period immediately following ovulation, in relation to the growth of the CL, could help to evaluate the possible role of this hormone in quantitative aspects of luteal growth.

McLeod, Haresign \& Lamming (1982) have shown that a pulsatile pattern of administration of small doses of LHRH for 8 days in seasonally anoestrous ewes resulted in ovulation with normal luteal function. Results obtained with this prolonged treatment schedule are consistent with either of the two hypotheses offered here to explain the inadequacies of some CL produced by bolus injections of LHRH. Since McLeod et al. (1982) did not observe a 'preovulatory-type LH peak' until $17-48 \mathrm{~h}$ after the start of treatment, although transient rises in plasma LH occurred after each injection, it is likely that follicular development was promoted before the LH surge. Similarly, the continuation of LHRH administration in the post-ovulatory period may have led to raised plasma concentrations of $\mathrm{LH}$ at this time, and thus promoted luteal growth.

In conclusion, small size of the $C L$ induced during anoestrus in this study was due primarily to the low numbers and small volumes of the luteal cells in these CL. The evidence suggests that both subnormal size of the CL, and subnormal progesterone production per luteal cell, contributed to the low plasma progesterone concentrations observed in anoestrous ewes induced to ovulate by the administration of LHRH. However, no evidence was obtained of diminished responsiveness to LH by the luteal cells of LHRH-treated ewes. Further investigation of the causes of the differences between normal cyclic $\mathrm{CL}$ and small CL formed following LHRH-induced ovulation during seasonal anoestrus could be directed towards the relationship between follicular and luteal cell numbers, and towards the endocrinology of the post-ovulatory period.

We thank Mrs Anne Bartlett, Mr Robert Bothof, Mr Phillip Smith and Mr Ken Snibson for excellent technical assistance; Dr R. I. Cox for providing the antiserum to progesterone; the NIAMDD for purified ovine LH ; and Professor G. C. Ryan for providing access to the 'Videoplan' image analyser. This work was supported by a grant from the Australian Meat Research Committee. 


\section{References}

Bedford, C.A., Harrison, F.A. \& Heap, R.B. (1972) The metabolic clearance rate and production rate of progesterone and the conversion of progesterone to 20๔-hydroxypregn-4-en-3-one in sheep. J. Endocr. 55, 105-118.

Burger, H.G., Lee, V.W.K. \& Rennie, G.C. (1972) A generalized computer programme for the treatment of data from competitive protein binding assays including radioimmunoassays. J. Lab. clin. Med. 80, 302-312.

Crighton, D.B., Foster, J.P., Haresign, W. \& Scott, S.A. (1975) Plasma LH and progesterone levels after single or multiple injections of synthetic LH-RH in anoestrous ewes and comparison with levels during the oestrous cycle. J. Reprod. Fert. 44, 121-124.

Fitz, T.A., Mayan, M.H., Sawyer, H.R. \& Niswender, G.D. (1982) Characterization of two steroidogenic cell types in the ovine corpus luteum. Biol. Reprod. 27, 703-711.

Haresign, W. \& Lamming, G.E. (1978) Comparison of LH release and luteal function in cyclic and LH-RHtreated anoestrous ewes pretreated with PMSG or oestrogen. J. Reprod. Fert. 52, 349-353.

Haresign, W., Foster, J.P., Haynes, N.B., Crighton, D.B. \& Lamming, G.E. (1975) Progesterone levels following treatment of seasonally anoestrous ewes with synthetic LH-releasing hormone. J. Reprod. Fert. 43, 269-279.

Hossain, M.I., Lee, C.S., Clarke, I.J. \& O'Shea, J.D. (1979) Ovarian and luteal blood flow, and peripheral plasma progesterone levels, in cyclic guinea-pigs. $J$. Reprod. Fert. 57, 167-174.

Long, C., King, E.J. \& Sperry, W.M. (1968) In Biochemists' Handbook, pp. 1070-1072. E. \& F. N. Spon Ltd, London.

McClellan, M.C., Diekman, M.A., Abel, J.H. \& Niswender, G.D. (1975) Luteinizing hormone, progesterone and the morphological development of normal and superovulated corpora lutea in sheep. Cell Tiss. Res. 164, 291-307.

McLeod, B.J., Haresign, W. \& Lamming, G.E. (1982) The induction of ovulation and luteal function in seasonally anoestrous ewes treated with small-dose multiple injections of Gn-RH. J. Reprod. Fert. 65, 215-221.

McNatty, K.P., Gibb, M., Dobson, C. \& Thurley, D.C.
(1981) Evidence that changes in luteinizing hormone secretion regulate the growth of the preovulatory follicle in the ewe. Endocrinology 90, 375-389.

McNeilly, A.S. \& Land, R.B. (1979) Effect of suppression of plasma prolactin on ovulation, plasma gonadotrophins and corpus luteum function in LH-RH-treated anoestrous ewes. J. Reprod. Fert. 56, 601-609.

McNeilly, A.S., Hunter, M., Land, R.B. \& Fraser, H.M. (1981) Inadequate corpus luteum function after the induction of ovulation in anoestrous ewes by LH-RH or an LH-RH agonist. J. Reprod. Fert. 63, 137-144.

O'Shea, J.D., Cran, D.G. \& Hay, M.F. (1979) The small luteal cell of the sheep. J. Anat. 128, 239-251.

O'Shea, J.D., Cran, D.G. \& Hay, M.F. (1980) Fate of the theca interna following ovulation in the ewe. Cell Tiss. Res. 210, 305-319.

Phillips, H.J. (1973) Dye exclusion tests for cell viability. In Tissue Culture: Methods and Applications, pp. 406408. Eds J. Kruse \& J. Patterson. Academic Press, London.

Rodgers, R.J. \& O'Shea, J.D. (1982) Purification, morphology, and progesterone production of three cell types isolated from the corpus luteum of the sheep. Aust. J. biol. Sci. 35, 441-455.

Rodgers, R.J., O'Shea, J.D. \& Findlay, J.K. (1983) Progesterone production in vitro by small and large ovine luteal cells. J. Reprod. Fert. 69, 113-124.

Rodgers, R.J., O'Shea, J.D. \& Bruce, N.W. (1984) Morphometric analysis of the cellular composition of the ovine corpus luteum. J. Anat. (in press).

Sokal, R.R. \& Rohlf, F.J. (1969) Biometry. W. H. Freeman and Co., San Francisco.

Swift, A.D. \& Crighton, D.B. (1980) The effects of injecting (D-Ser $\left.\left(\mathrm{Bu}^{t}\right)^{6}\right)$ des $\mathrm{Gly}-\mathrm{NH}_{2}{ }^{10}$ luteinizing hormone releasing hormone ethylamide in early, mid and late seasonal anoestrus on gonadotrophic secretion and luteal function in the ewe. Theriogenology 14, 269-279.

Weibel, F.R. (1979) Stereological Methods, vol. 1. Practical Methods for Biological Morphometry. Academic Press, London.

Wright, P.J., Geytenbeek, P.E., Clarke, I.J. \& Findlay, J.K. (1980) Pituitary responsiveness to LH-RH, the occurrence of oestradiol-17 $\beta$-induced LH-positive feedback and the resumption of oestrous cycles in ewes post partum. J. Reprod. Fert. 60, 171-176. 